\title{
VOCATIONAL CURRICULUM IMPLEMENTATION OF THE THREE YEARS PROGRAM OF ELECTRONICS ENGINEERING
}

\author{
Lipur Sugiyanta ${ }^{1}$, Moch. Sukardjo ${ }^{2}$, M. Khairudin ${ }^{3}$, Irdayanti Mat Nashir ${ }^{4}$ \\ ${ }^{12}$ Department of Electronics Engineering Education, Universitas Negeri Jakarta, Indonesia \\ ${ }^{3}$ Department of Electrical Engineering Education, Universitas Negeri Yogyakarta, Indonesia \\ ${ }^{4}$ Fakulti Teknikal dan Vokasional Universiti Pendidikan Sultan Idris, Perak, Malaysia \\ E-mail: lipurs@unj.ac.id
}

\begin{abstract}
This study analysed the implementation of the Indonesian Qualification Framework based vocational curriculum in the three years program of an electronics engineering, Faculty of Engineering, Universitas Negeri Jakarta. The analysis was focused on lecturers and students' views. This evaluation used the model of Context, Input, Process, Product by involving 49 students in the $3^{\text {rd }}$ semester, 6 lecturers, and administration staff. The findings showed that the implemented learning activities using the new curriculum paradigm are reliable. The context analysis indicated the correlation between lecturers' competence and qualification and the goals of the study program. The input analysis showed that the lecturer's assignment was appropriate and correspond with lecturers' subject and education background. The process analysis revealed that the learning process was in accordance with the lectures' planning. In addition, the practicum activities were reportedly consistent with the academic calendar. The product analysis, in the form of courses distribution each semester, suggested that the needs for improvement to fit the new curriculum paradigm design.
\end{abstract}

Keywords: analysis, electronics engineering, three years program, vocational curriculum

\section{INTRODUCTION}

The quality of learning activities should remain to meet the standards and demands of national or international standards of learning outcomes and graduates' competencies. The official reference used was the Presidential Regulation number of 8 with the year of 2012 which sets the Indonesian Qualification Framework (IQF) [1]. IQF is the framework of the Indonesian employment qualification and competence that matches, equalizes, and integrates among education sectors, training sectors, and work experience in a job-adjusted capability recognition in various schemes.

Work competencies required in a particular sector is important to prepare students to live, to work, and to be successful in this challenging situation [2]. Therefore, qualification levels had to be nationally agreed to learn achievement level based on the educational and/or training outcome obtained through formal, non-formal, informal, or work experiences.
IQF provides nine levels of qualification, starting from qualification of level $1^{\text {st }}$ to level $9^{\text {th }}$. Determination of the qualification levels was conducted through a comprehensive mapping of labor conditions in Indonesia in terms of the needs of the suppliers (supply pull) and the user (demand pull). Each level on IQF has its own descriptor. Each descriptor consists of two parts, the general description, and specific description. General descriptions describe the character, personality, attitude in work, ethics, morals and are applied at every level, while the specific description describes the scope of science, knowledge, understanding, and skills that depend on the level. Those four parameters achieved with learning achievement, through formal education process within the National Education System (academic, vocational, and professional education programs) or through work experience within the National Certification System (career and experience development). Higher Education may add other (specific) capabilities to the graduates, included in the category of supporting and preferred 
competencies, or special competencies according to the standard classification of the National Professional Certification known as Badan Nasional Sertifikasi Profesi (BSNP).

The study program of three years program of electronics engineering is a type of vocational education, which set its goals to equip the graduates with skills to be ready to work and to compete in electronics fields globally [3][4]. The expected competencies were shown in Table 1.

Table 1. Graduates' Expected Competences

\begin{tabular}{ll}
\hline No & \multicolumn{1}{c}{ Main Competences } \\
\hline 1. & $\begin{array}{l}\text { capable of completing wide-ranging works by } \\
\text { applied selected appropriate methods from } \\
\text { various standardized options and data } \\
\text { analyzing, and able to perform with measurable } \\
\text { quality and quantity criteria }\end{array}$ \\
2. & $\begin{array}{l}\text { understand the general concepts of electronics } \\
\text { knowledge, and able to formulate problem- } \\
\text { solving procedurally }\end{array}$ \\
able to manage the teamwork and prepare a \\
comprehensive report \\
r.
\end{tabular}

To meet these competencies, the graduates of the three years program of electronics engineering must have the soft skill and hard skill, and be adaptive to the demands of work and technology. The three years program of the electronics engineering in Faculty of Engineering, Universitas Negeri Jakarta established since May 21 in the year of 1999 had several curriculum upgrades. At present, it has applied the curriculum of higher education based on higher education national standards and IQF level 5. Since the beginning of implementation, the performance of the study program by using the new curriculum has never been evaluated. For that reason, this analysis of the new vocational curriculum implementation is crucial.

The three years program of the electronics engineering in Faculty of Engineering, Universitas Negeri Jakarta had excellence in the field of industrial automation. The total credits for education were 111 credits and scheduled for 6 semesters (average credits number distribution of 20 to 23 for each semester). The graduates will hold an associate's degree.
These goals were in line with the results obtained from Arifin et al [5] and Supriyadi [6] suggesting that vocational education manages education to prepare the students with applied skills in particular fields. Using the Context, Input, Process, Product (CIPP) method, the evaluation results obtained from the implementation of the 2009 curriculum in the study program was quite good. The lecturers or alumni and students were $75.81 \%$ and $64.64 \%$ respectively stated that the curriculum was compatible, although there were weaknesses in some aspects.

Several aspects that need to be improved from the context aspects were the alignment of vision and mission with the curriculum and conformity with the real industrial environment and community. Some lecturers did not comprehend the curriculum outline. The subject's material compliance with the used handbook references was inadequate. The facilities provided during the practical course was less appropriate. The time provided for discussion with lecturers was limited, yet this discussion was important for students to exchange ideas.

Some suggestions are needed to improve the curriculum implementation in the future. They are more intensive socialization to lecturers and students as well as related entities, lecture materials improvement according to curriculum contents, fulfillment of tools and materials for practice (laboratories) and upgrading learning administration system. Handayani et al. [7] also emphasized on the importance of curriculum evaluation to address the challenges of vocational education in the future. Some of the challenges are (1) to achieve the labor market needs, (2) to be developed for several profession competences, (3) to answer the challenges of works in the area of industrial electronics, measurement, and production process, (4) some work belongs to the R \& D can be performed by students under supervision, (5) the portion of work vacancies currently not occupied by the graduate of associate's degree program. 


\section{METHOD}

This study was categorized as evaluative research using the Context, Input, Process, Product (CIPP) model. The model was designed to systematically guide both evaluators and stakeholders in posing relevant questions and conducting assessments at the beginning of a project (context and input evaluation), while it is in progress (input and process evaluation), and at its end (product evaluation or evaluation of outcome) [8].

This study was conducted from May to November of 2016. The population consisted of students, lecturers, and administration staff with the number of 49, 6 and 1 respectively. Primary data were collected through questionnaires and interviews. The number of $62 \%$ of students responded the questionnaires. The secondary data including the students' data in each semester, the list of industries/schools that employed graduates, and the lecturers were used. The variables employed as primary data and secondary data are listed in Table 2 . The data obtained were tabulated, processed, and expressed in percentages then interpreted as research findings.

Table 2. Research Variables

\begin{tabular}{|c|c|c|c|c|}
\hline & Context & Input & Process & Product \\
\hline Primary Data & $\begin{array}{l}\text { - Questionaires for } \\
\text { lecturers } \\
\text { - Questionaires for } \\
\text { students }\end{array}$ & $\begin{array}{l}\text { - Questionaires for } \\
\text { lecturer } \\
\text { - Questionaires for } \\
\text { students }\end{array}$ & $\begin{array}{l}\text { - Questionaires for } \\
\text { lecturer } \\
\text { - Questionaires for } \\
\text { students } \\
\text { - Interviews with study } \\
\text { program coordinators }\end{array}$ & \\
\hline $\begin{array}{l}\text { Secondary } \\
\text { Data }\end{array}$ & $\begin{array}{ll}\text { - } & \text { Curriculum } \\
& \text { references } \\
\text { - } & \text { Regulations } \\
\text { - Learning outcomes } \\
\text { - Self-evaluation for } \\
\text { accreditation }\end{array}$ & $\begin{array}{l}\text { - Number of lecturers } \\
\text { - Number of research } \\
\text { - Certificates of } \\
\text { lecturer } \\
\text { - Infrastructure } \\
\text { - Number of students } \\
\text { at academic year } \\
2014 / 2015 \\
\text { - Number of registered } \\
\text { students at academic } \\
\text { year } 2014 / 2015 \\
\text { - GPA of the students } \\
\text { each semester }\end{array}$ & $\begin{array}{l}\text { - Lecturer workload } \\
\text { - Documentation of } \\
\text { lectures and practices } \\
\text { (laboratory) } \\
\text { - Examination/test }\end{array}$ & $\begin{array}{l}\text { - Graduates at } \\
\text { academic year } \\
2014 / 2015 \\
\text { - Employees } \\
\text { - Final assignment }\end{array}$ \\
\hline
\end{tabular}

\section{RESULTS AND DISCUSSION}

The research results on context instrument (lecturer) explained that the establishment of the study program was not primarily caused by the number of High Schools graduates, but due to the need of the community. This conclusion is supported with the following response: (a) most of lecturers with the percentages of $66.7 \%$ doubted the establishment of the study program was related to the fact that many senior high schools or senior vocational school graduates were not accommodated, (b) half of lectures disagree or strongly disagree whether the goals of the study program was to accommodate all high school graduates in higher education level while the percentages of the lectures who strongly disagree, disagree, doubt and agree were $16.7 \%, 33.3 \%, 33.3 \%$, and $16.7 \%$ respectively, (c) most of the lecturers with the percentage of $63.7 \%$ agree and strongly agree that the background of the study program was to meet the needs of the industrial work.

Most of the lecturers with the percentage of $83.3 \%$ agree that graduates were expected to have skills, attitude, high discipline, and a good mentality, but only a few lecturers with the percentage of $16.7 \%$ strongly agree that vocational education that was different from the bachelor's degree program. A total of $66.67 \%$ of 
the lecturers doubt the clear difference between the study program with a bachelor's degree study program. A total of $66.7 \%$ lecturers strongly disagree that the study program was for students whose low intellectual rank compared to bachelor's degree program. Almost all lecturers agree that the student's intellectual level was equivalent to the students in the bachelor's degree program (not the rest of the failed applicant from the bachelor's degree program admission). All lecturers agree that students have the spirit to complete study on Time.

The majority of lecturers stated that the graduates of high schools still need to be improved in academic ability, skills, and attitude thus, the study program with a new curriculum paradigm was in accordance with the needs of the stakeholders. This conclusion is supported by the following respond: (a) most of lectures with the percentage of $66.67 \%$ agree that the study program was expected to develop students' thinking and reasoning comprehensively, (b) most of lectures with the percentage of $66.67 \%$ support that the students were expected to have good academic achievement, (c) half of lecturers state that practicum requirement for students has been fulfilled, (d) half of lecturers agree that students whose high skills required special attention and services. Lecturers who answered doubt may not know what kind of attention and services were needed for those students.

Context analysis for lecturers obtained the result that the majority of lecturers: (a) understand the background and goals of the study program establishment, (b) understand the implementation of new curriculum paradigm, although few of them have different thoughts, (c) stated that vocational education should be carried out differently from bachelor's degree programs, especially in skills, to meet the needs of the industrial environment. Therefore, the quality of education service and the quality of graduates still need to be improved on academic abilities, skills, and attitudes.

The lecturers understand how to select new students. This conclusion is supported by the following response: (a) most of the lecturers with the percentage of $60 \%$ agree that students from the vocational high school graduates more preferable than high school graduates, (b) all lecturers agree that more new students accepted through independent admission scheme compared to the national admission test was better, (c) all lectures doubt with the percentage of $40 \%$ or disagree with the percentage of $60 \%$ that the new students' rank from the national admission test was low.

All lecturers strongly agree with the percentage of $60 \%$ and agree with the percentage of $40 \%$ that lecturers' education of associate's degree must be linear with a master's degree. Most of the lecturers with the percentage of $60 \%$ agree that the total of credits has been in accordance with the curriculum. Only $20 \%$ of lecturers disagreed to the statements of (a) the content of the course should more practice than theory, (b) the practicum and theory should be in balanced.

The training for the new curriculum paradigm was not mandatorily required. This result was according to the following respond: (a) most of lecturers with the percentage of $60 \%$ agree that course descriptions matched the demands of the industrial market, (b) all lecturers gave lecture using modules designed by themselves, (c) most of the lecturers with the percentage of $60 \%$ expressed doubt to the statement that midterm examination and final examination demanded logic and high-level thinking, (d) most of the lecturers agree with the percentage of $60 \%$ to statement that exam questions always refers to learning achievement design and learning activities plan.

An only small portion of lecturers do research consistently. The results showed the lectures doubt that subject materials were always related to research, use the latest book reference and ensure that latest moduls and guidebooks were available for the students with the number of 80, 60 and 60 percentages respectively.

The infrastructure and supporting facilities were not fully available. The following results showed: (a) only $40 \%$ of lecturers stated that the classroom was equipped with $\mathrm{WiFi},(\mathrm{b})$ 
$20 \%$ of lecturers stated that LCD was always available in the classroom, (c) only $40 \%$ lecturers stated that tools in the laboratory were available and ready to use, (d) $60 \%$ of lecturers stated that materials for laboratory were not always available, (e) $60 \%$ of lecturers stated that ratio of classroom scale was not in accordance to the number of students, (f) forty percent (40\%) of lecturers stated that electricity for practicum was adequate, (g) $60 \%$ of lecturers stated that Occupational Safety and Health equipment were not fully functional, (h) $40 \%$ of lecturers stated that air circulation in laboratory was adequate, and (i) $40 \%$ of lecturers stated that laboratory assistants were not always ready. Inputs analysis for lecturers provided the result that most of the lecturers had the appropriate academic workload, although infrastructure and supporting facilities were inadequate.

The result in process instrument (lecturer) showed that the analysis of the returned questionnaire gives the following results. The lecturer's preparation in setup learning activities was prepared well enough. This conclusion is supported by the following response: (a) only a few lecturers with the percentage of $40 \%$ disagreed that workload distribution of teaching should be delivered long before the lecture takes place, (b) $60 \%$ of lecturers agreed that offered courses for each semester should be arranged far before lectures take place, (c) $60 \%$ of lecturers agreed to statement that offered courses for each semester should be informed to students and lecturers far before lectures take place, (d) 60\% of lecturers agreed with lecture's preparation, (e) $60 \%$ of lecturers agreed that materials should be offered to the students in advanced.

There was no lecturer needed comes from an industrial background yet. $60 \%$ of lecturers were doubt about the need for lecturer's background from the industrial world. Lecturers were able to adapt to learning environment conditions. This conclusion is supported with the following response: (a) most of lecturers with the percentage of $60 \%$ could accept frequently schedule's change, (b) $60 \%$ of lecturers agreed that first lecture at each semester always on time, (c) most of lecturers with the percentage of $60 \%$ doubt the schedule was delivered through the website, (d) most of lecturers with the percentage of $60 \%$ agreed that schedule was more appropriate posted manually by notice board to students, (e) most of lecturers with the percentage of $60 \%$ agreed that total face to face in classes should meet the requirements of semester credit unit, (f) all lecturers agreed that class's attendance in the classroom should be started on time and completed on time, (g) most of the lecturers with the percentage of $60 \%$ agreed that the semester learning plan should be prepared at the beginning of the lecture, (h) $60 \%$ of lecturers doubt that lectures in one semester not in line with planned semester learning plan. Many lecturers obeyed the study program convention and gave a lecture in accordance with planned semester learning plan.

Lecturers kept on the commitment that the tasks, assignments, and exams were given to provide more understanding about the course. Students' grades should dominate on practical abilities compared to assessments based on theory. This conclusion is supported with the following response: (a) all lecturers agreed and strongly agreed that teaching media should used during lecture, (b) most of lecturers with the percentage of $60 \%$ agreed to deliver tasks and assignments for students regularly, (c) only $40 \%$ of lecturers agreed to give the final exam orally, (d) most of lecturers with the percentage of $60 \%$ agreed that final exam was always written, (e) few lecturers with the percentage of $40 \%$ disagreed and rest of them were doubt to set final examination mostly related to theories, (f) all lecturers support that final examination for practicum must be completed as planned, $(\mathrm{g})$ most of the lecturers with the percentage of $60 \%$ agreed to always return students' assignments, tasks, and exams, (h) all lecturers agree to always return midterm and final examination papers. On the other hand, only $40 \%$ lecturers agreed to improve the quality of teaching by using the newest books or references.

Guidance for students to complete the final project received a good response from the 
lecturers. This conclusion is supported with the following response: (a) $60 \%$ of lecturers agreed to give routine guidance to students until submitting final projects and other academic consultations related, (b) all lecturers agree to always reply messages related to academic from students, (c) all lecturers agree to give solutions if students have problems related to academic activities, (d) all lecturers agree to provide regular time for students' consultation. These response showed that improvement of student services by lecturers was needed, and lecturers did not have difficulty by using social media communication.

Supports for students to complete their final projects are not optimal. Most of the lecturers did not provide the best solutions for students at the final project seminars. This happened because few lecturers do have experiences in the field of industrial environment. This conclusion is supported by the following respons: (a) all lecturers agreed that facilities for student's seminar should available, (b) all lecturers agreed that seminars related to the study completion should be held regularly, (c) most lecturers with the percentage of $33 \%$ disagree and $50 \%$ doubt to give the best solution for students during the seminar, (d) most of lecturers doubt with the percentage of $60 \%$ that lecturers' assignment as final project advisers based on the industrial expertise. From the analysis above, the conclusion of the lecturer's process is that the process of lecture meets the expectation.

The research result on context instrument (students) showed that the establishment of study program had been in line with the needs of stakeholders. Only a few students doubt the clear difference between the study program and the bachelor's degree study program. This conclusion is supported with the following respons: (a) most of the students with the percentage of $66.7 \%$ strongly agree that students for the study program did not have lower intellectual ability than bachelor's degree program, (b) most of students with the percentage of $66.67 \%$ doubt that the goals of the study program was to accommodate all high schools graduates in higher education level, (c) half of lectures disagree or strongly disagree to the goals of the study program was to accommodate all high school graduates in higher education level, (d) half of students agreed that background of the study program was to meet the needs of the industrial work, but (d) few students with the percentage of $33.7 \%$ agreed and strongly agreed that the vocational study program was different from the bachelor's degree program, (e) most of the students with the percentage of $60 \%$ disagreed that more new students will be accepted through independent admission compared to national admission, (f) all students disagreed that new student's rankings from national admission scheme were low.

Half of the student stated that the graduates of high schools still need to be improved in academic ability, skills, and attitude. This conclusion is supported by the following respond: (a) although $83.3 \%$ of students agreed that graduates should have skills, attitude, high discipline, and good mentality, but $66.6 \%$ of students doubt to complete the study on time, (b) all students agreed to have practical skills completely, (c) half of students agreed to the question of the study program was expected to develop student's thinking and reasoning comprehensively, (d) most of students with the percentage of $66.67 \%$ agree that students whose high skills potentials required special attention and services, (e) all students doubt to what kind of special services were required for students with high ability.

The conclusion from student context analysis is students understand the background and goals of the study program, although there are several different ideas, and there are potentials to improve students' academic quality.

The result on input instrument (students) showed that the new curriculum paradigm was compatible with the mandatory industrial environment. This result was according to the following respond: (a) all students agreed that a 
total of semester credit unit has met with curriculum requirements, (b) all students agree to use modules designed by lecturer during learning, (c) $60 \%$ of students agree that course descriptions matched with the demands of the industrial market, (d) $60 \%$ of students doubt that midterm exam and final exam demanded logic and high-level thinking skills, (e) $80 \%$ of students doubt that exam questions should refer to the semester learning plan and learning achievement, (f) $60 \%$ of students agree that midterm exam and final exam meet the goals of the course, (g) $60 \%$ of students disagreed that exam questions always in the form of multiple choice questions, (h) $60 \%$ of students doubt that training about new curriculum paradigm for lecturers was not mandatory required.

New curriculum paradigm matched stakeholder's requirements. This result was according to the following respond: (a) all students agree that the content of the course is more practices than theory, (b) $80 \%$ of students agree that the equipment in the laboratory should meet the practical goals, (c) $60 \%$ of students disagree to the statement that practicum class and theoretical class should be balanced, (d) all students agree to have lecturers with linear qualification between associate's degree and master's degree

An only small portion of lecturers do research consistently. The following results showed: (a) $80 \%$ of students doubt that lecturer always conducts research related with the subjects taught, (b) most students disagree that lecturers used the latest book references, (c) all students agree that modules and guidebooks should be available for students.

The infrastructure and supporting facilities were not fully available. The results showed: (a) $80 \%$ of students agree that classrooms were equipped with $\mathrm{WiFi}$, (b) all students agreed that LCD projectors were available in the classroom, (c) $60 \%$ of students agree that tools for the laboratory were available, (d) $60 \%$ of students agree that laboratory's materials are always available, (e) $80 \%$ of students agree that the ratio of classroom scale should be in accordance with the number of students, (f) $60 \%$ of students disagree that electricity for practicum was sufficient, (g) $80 \%$ of students agreed that there were assistant during practicum class, (h) $60 \%$ of students agree that there was good air circulation in laboratory, (i) $60 \%$ of students disagreed that Occupational Safety and Health equipment was available.

In conclusion, $80 \%$ of the response were in accordance with the students' opinion. There were several items that are not appropriate for examples final exam questions that are not in accordance with the course plan, the balance between theory and practice, and the relevance of students' research with courses taken.

The research results on process instrument (students) explain that the lecturer's preparation in learning activities was good, but not all of the students got the materials offered in advance. This conclusion is supported with the following response: (a) $50 \%$ of the students agree that the distribution of the lecturer's teaching load was delivered long before the lectures take place, (b) $66.7 \%$ of students agree that lectures for each semester should be arranged far before lectures take place, (c) half of students agreed that lecture preparation meeting should be held by study program each semester, (d) $83,3 \%$ of the students agree that the schedule for the next semester was informed previously to the students and lecturers, (e) all students doubt about whether the materials should be submitted to students before lectures began.

From the side of lecturer background coming from the industrial world, $66.7 \%$ of students say agree and $16.7 \%$ are doubt, the remaining $16.7 \%$ stated disagree. It can be said that the students prefer to have lecturers with an industrial background.

Students were not able to adapt to changing learning conditions. This condition was caused by most of the lecturers did not follow the designed semester learning plan made at the beginning of the semester. This conclusion is supported with the following respons: (a) $83.3 \%$ of students doubt that course schedules 
should not be changeable, (b) $66.67 \%$ of the students agree that first lecture at the beginning of semester was always on time, (c) $66.67 \%$ of students doubt or disagree that course schedule was informed through the website, (d) $67.7 \%$ of students agree that course schedule was more appropriate posted by notice board to students, (e) all students agreed that total hours for each lecture complied with semester credit unit, (f) $67.7 \%$ of students agree that lecturers should attend and finish lectures on time, $(\mathrm{g}) 67.7 \%$ of students agree that lecturers should gave the preplanned semester learning plan at the beginning of the course, (h) $67.7 \%$ of students doubt that the lecturer should give substituted lectures to meet the semester learning plan, (i) all students agreed that teaching media should be used during the lectures, (j) half of students doubt that lecturers should give more understanding by delivering tasks on a regular basis. On the other hand, $67.7 \%$ of students doubt that lecturers always use the newest books or references to improve the quality of teaching.

Lecturers have low commitment to provide more tasks, assignments, and exams. Students' agree that practical abilities should dominate compared to assessments based on theories. This conclusion is supported with the following response: (a) all students agree that students' assignment forms always returned after reviewed, (b) $83.7 \%$ of the students agree that students' midterm exams and final exams always returned after being checked, (c) $67.7 \%$ students agree that final exams were written form, (d) $67.7 \%$ of students agree to have final exam orally, (e) $67.7 \%$ of students doubt that final exams are related to theories, (f) $67.7 \%$ of students doubt that final exams for practicum were completed as planned.

Support for students to complete the final projects did not receive a good response from the lecturers. The positive aspects were the selection of lecturers as advisor meet the field of expertise and communication through social media was not a problem for students and lectures. There need improvement in students' services by lecturers. This conclusion is supported by the following response: (a) most of students with the percentage of $33.3 \%$ disagree that lecturers guide students to submit a thesis (final projects) and other academic consultations, (b) most of students with the percentage of $83.3 \%$ agree that lecturers always reply to SMS/WhatsApp messages from students related to academic matters, (c) all students agree that lecturers always give solutions if there are academic activities problems, (d) all students agree that lecturers provide regular time for students' consultation, (e) most of the students with the percentage of $67.7 \%$ agree that the best solution for students' final project was always given, (f) half of students agree that assignment of final projects advisor based on the expertise of lecturers, but $(\mathrm{g})$ most of the students with the percentage of $83.3 \%$ disagree to availability seminar facility for students.

From the analysis, the conclusion on the students' process is in accordance with the expected goals, although there is still weakness in administration and class management. This result is similar to the review of Arifin et al. [5]. Based on the results of other research analysis of the curriculum [9]-[19] and the Focus Group Discussion (FGD) in the study program, the improvement to the existing curriculum is proposed. The proposed curriculum was first analyzed from courses description than by the instructional design. Course analysis was carried out by considering the following intensity (1) the current structure of courses presented in Figure $1,(2)$ the distribution of courses per semester, (3) the structure of courses that should be changed presented in Figure 2, and (3) distribution of proposed courses in each semester presented in Figure 3.

Figure 3 shows the proposed the revised curriculum (based on curriculum evaluation year 2015). Green color shows the courses distribution in $5^{\text {th }}$ semester. Light brown color shows the courses distribution in $4^{\text {th }}$ semester. Brown color indicates the courses distribution in $3^{\text {rd }}$ semester. Yellow color shows the courses distribution in $2^{\text {nd }}$ semester. Light blue color shows the courses distribution in $1^{\text {st }}$ semester. 
The course's structure employs a packet scheme with a maximum credit of 110 -semester credit units. Courses groups are (a) 11 credits of general courses, (b) 29 credits of basic expertise courses, (c) 20 credits of learning courses, (d) 50 credits of advanced expertise courses. General courses and learning courses were in light blue and yellow (half). Basic expertise courses were in yellow (half) and brown. Advanced expertise courses were in light brown and green. They are presented in Figure 1.
The change of courses structure was designed to give the students opportunities to more concentrate on the expertise that the students choose. It also encourages the students to follow the courses flow easier. The designed tree of courses had already complied with the Electrical Engineering field. Figure 2 showed the transition changes in the structure of the existing course.

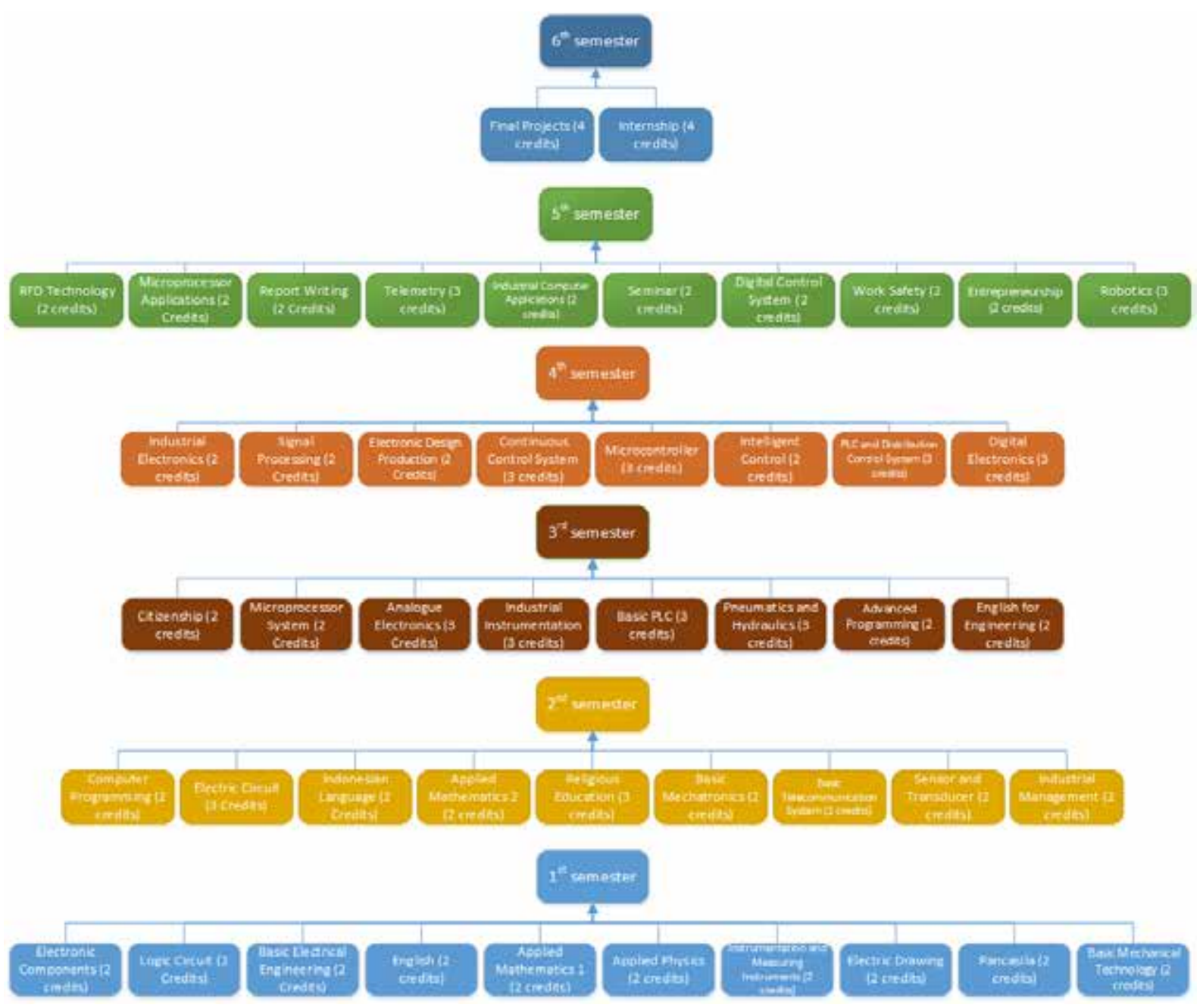

Figure 1. Courses Composition of the Existing Curriculum (2015) 


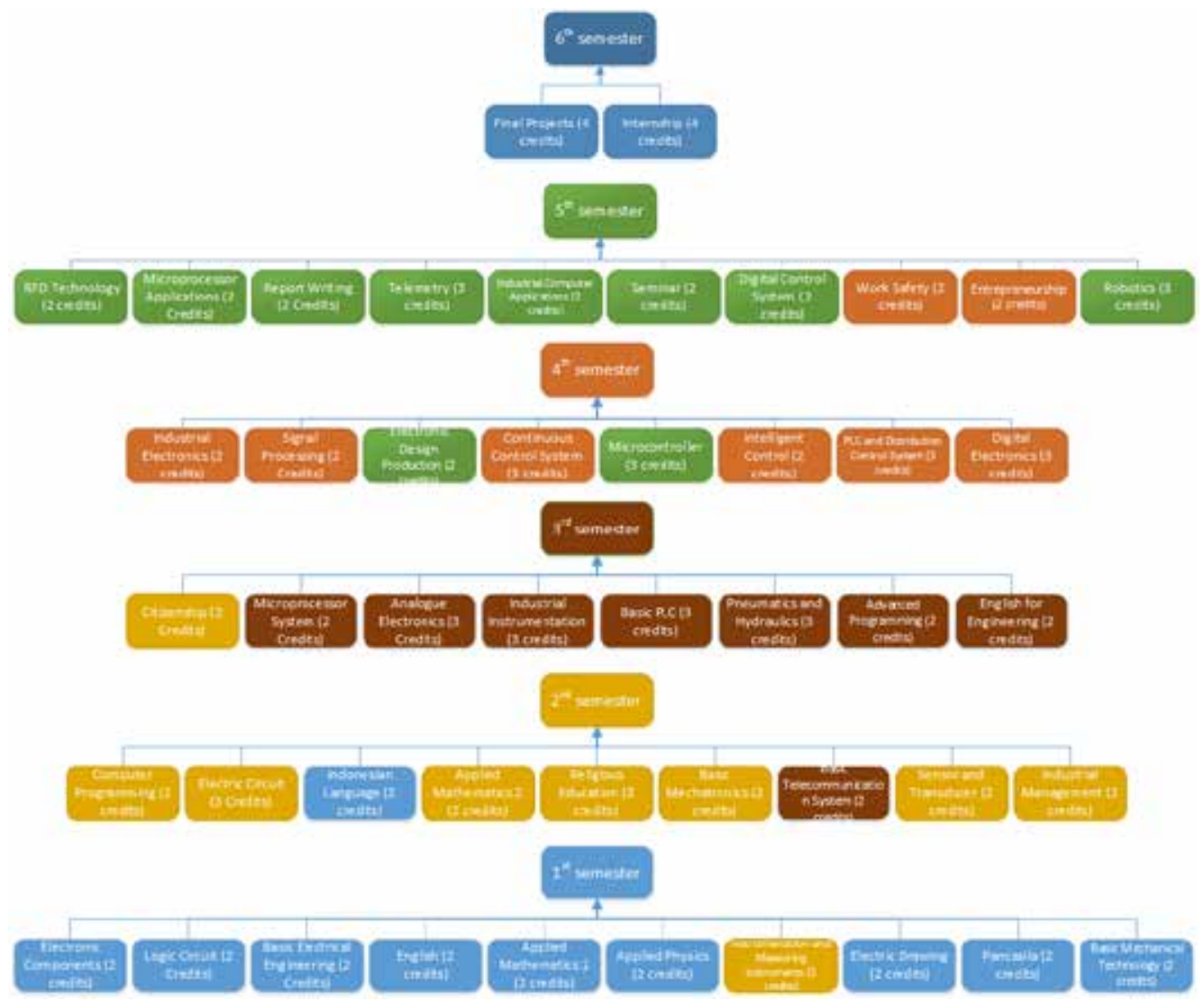

Figure 2. Proposed of Revised Curriculum (Based on Curriculum Evaluation Year 2015)

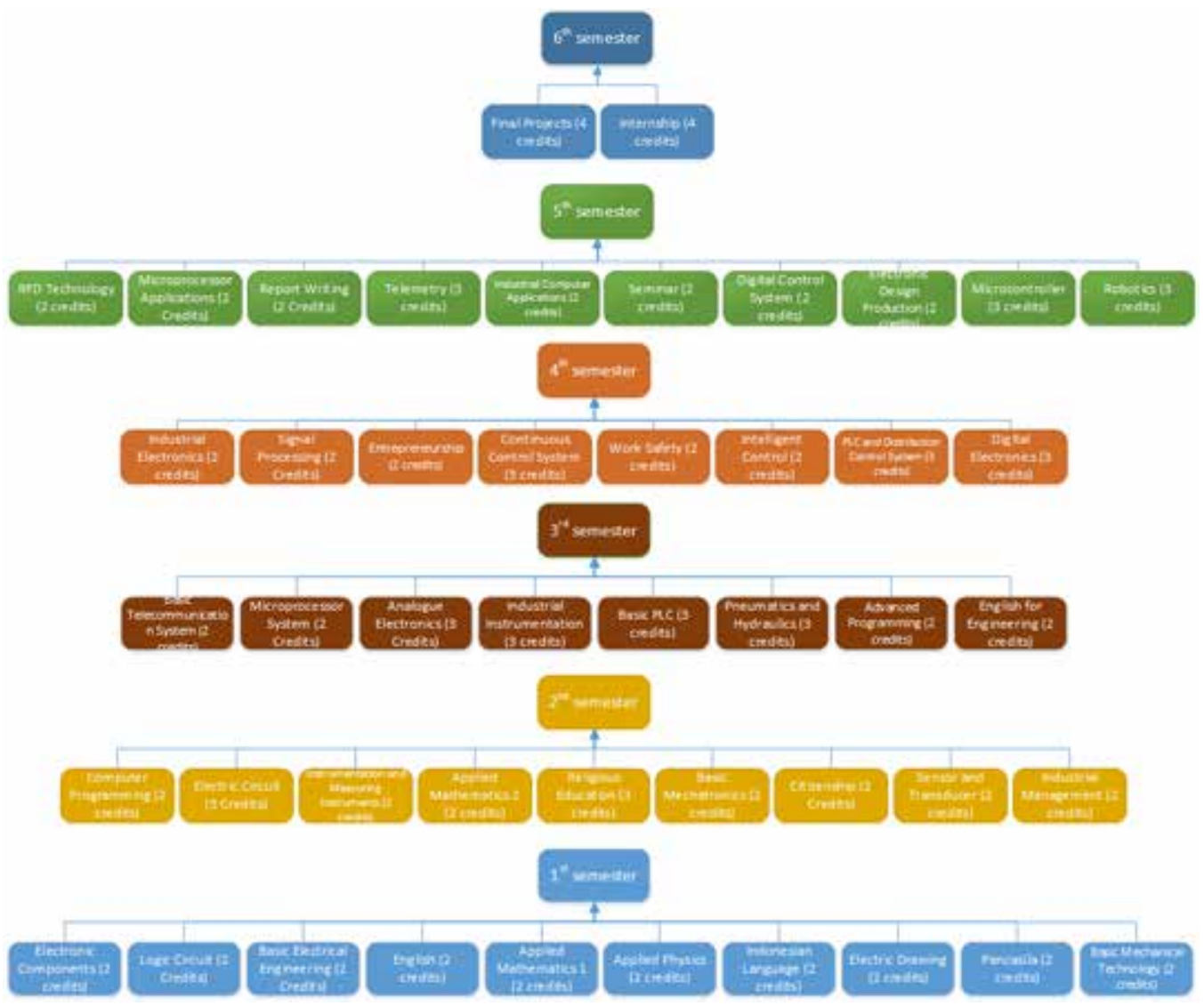

Figure 3. Structure of Proposed Revised Curriculum 


\section{CONCLUSION}

The study program should accommodate the public and industrial demands. Blended industrial elements in the learning process (preparing students to be ready for work) and increase the opportunity for graduates to continuing their education to higher education levels were among the demanded things. The associate's degree program of Electronics Engineering has adapted the new curriculum based on IQF since 2012. Adaptation and evaluation of new curriculum implementation have been confirmed through the research results by using the CIPP model. The curriculum achieved through practicum, lectures or other academic services. Some internal potentials becoming the strengths were: (a) students have high motivation to complete their study on time, (b) having good lecturers both in terms of theoretical aspects and laboratory works, (c) time allocation for theoretical and practical lectures had been conducted balanced. The constraints experienced by the study program were: (a) lack of updated references in the form of journals and books, and (b) the high students' task load during the study potentially extend the study period. The study program needs to be maintained because its existence is appropriate and relevant to the needs of students and stakeholders. Advanced studies are needed to confirm whether the proposed revised curriculum was relevant to the stakeholder goals.

\section{REFERENCES}

[1] Secretariat Cabinet of the Republic of Indonesia, Peraturan Pemerintah Nomor 8 tahun 2012 tentang Kerangka Kualifikasi Nasional Indonesia. Indonesia, 2012.

[2] E. P. Widoyoko, Penilaian Hasil Pembelajaran di Sekolah. Yogyakarta: Pustaka Pelajar, 1994.

[3] T. and H. E. Ministry of Research, Kepmenristekdikti nomor 257/M/KPT/2017 tgl 5 September 2017 tentang Nama Program Studi pada Perguruan Tinggi. Indonesia, 2017.

[4] Ministry of Education and Culture, "SK no. 5041/D/T/K-N/2010 tanggal $21 \mathrm{Mei}$ 1999 tentang Pembukaan Program Studi Teknik Elektronika," 2010.

[5] Z. Arifin, M. Martubi, K. Haryana, M. Solikin, and I. Siswanto, "Penyelarasan Kurikulum Jurusan Pendidikan Teknik Otomotif FT UNYBerbasis Kerangka Kualifikasi Nasional Indonesia," $J$. Pendidik. Teknol. dan Kejuru., vol. 22, no. 1, pp. 119-126, 2014.

[6] E. Supriyadi, "Kajian Kurikulum Jurusan Pendidikan Teknik Elektro Fakultas Teknik Universitas Negeri Yogyakarta Mengacu pada Kerangka Kualifikasi Nasional Indonesia," J. Pendidik. Teknol. dan Kejuru., vol. 21, no. 2, pp. 156-166, 2012.

[7] P. Handayani, T. Y. Putro, E. Rakhman, and S. J. -Ching, "Learning Outcomes Mapping of the Three Year-Electronic Engineering Diploma in Level-5 Professional Expertise of the National Qualification Framework," J. Pendidik. Teknol. dan Kejuru., vol. 24, no. 1, pp. 102-115, Apr. 2018.

[8] J. C. Galvin, "What Can Trainers Learn from Educators about Evaluating Management Training?," Train. Dev. J., vol. 47, no. 2, pp. 228-244, 1983.

[9] H. Bowers, "Curriculum Design in Vocational Education," in Australian Association for Research in Education 2006 Conference, 2006.

[10] M. L. Donna., "Implementing a Holistic Approach in Vocational Education and Training," Aust. J. Adult Learn., vol. 47, no. 2, pp. 228-244, 2007.

[11] J. Wang, "The Comparison and Inspiration of Outcome-based Curriculum Design in Canada and Higher Vocational Education in China," in 2nd International Conference on Management Science and Industrial Engineering (MSIE 2013), 2013, pp. 709-712.

[12] M. Holland, M. Coldwell, S. Trickey, and B. Morgan, "The Development of the Secondary Vocational Curriculum in a Northern Local Authority in England," in European Conference of Education Research (ECER VETNET Conference 
2007), 2007.

[13] D. Laird and J. Stevenson, "A Curriculum Development Framework for Vocational Education," Aust. New Zeal. Joumal Vocat. Educ. Res., pp. 71-92, 1993.

[14] L. Geleto, "Technical Vocational Education Training Institute Curriculum Development in Ethiopia," $J$. Educ. Vocat. Res., vol. 8, no. 3, pp. 16-28, 2017.

[15] N. J. Walters, "Curriculum: Framework for the Future," J. Vocat. Tech. Educ., vol. 5, no. 1, pp. 28-39, 1988.

[16] J. W. Rojewski, "A Conceptual Framework for Technical and Vocational Education and Training," in International Handbook of Education for the Changing World of Work, R. Maclean and D. Wilson, Eds. Berlin: Springer, 2009, pp. 19-39.
[17] A. D. Minghat and R. M. Yasin, "Sustainable Framework for Technical and Vocational Education in Malaysia," Procedia Soc. Behav. Sci. 9, vol. 9, pp. 111233-1237, 2010.

[18] Y. Zhang and L. Li, "Construction of Curriculum According to a CompetencyBased Curriculum Framework for The Specialty of Health Information Management in Higher Vocational Colleges," in IEEE International Symposium on IT in Medicine and Education 2011, 2011.

[19] P. Boahin, "Competency - Based Curriculum: A Framework for Bridging the Gap in Teaching, Assessment and the World of Work," Int. J. Vocat. Tech. Educ. Res., vol. 4, no. 2, pp. 1-15, 2018. 